\title{
Emotional Responses to Top Politicians in a General Election
}

\author{
Flemming Hansen, Steen Lundsteen \\ \& Sverre RiIs Christensen
}

\begin{abstract}
Voting behaviour has been studied as a specific form of individual behaviour and has primarily been seen as the result of reflection and deliberation on behalf of the individual. In general consumer behaviour research, the focus is increasingly on the seemingly unconscious and emotionally controlled processes that seem to shape a large part of consumer responses to brands, services and communication. The objective of this paper is to study the influence that emotional reactions have on voter behaviour in connection with a general election. The opportunity arose to carry out a pre- and a post-evaluation of voters' emotional responses to 6 major party leaders. The results support the notion that constant or increasing positive emotional reaction does in fact accompany election success, whilst election failure is accompanied by decreasing levels of emotional response. The results and their implications for political marketing in the context of an election are discussed.
\end{abstract}

Key Words: voting behaviour, emotional responses, general election

\section{Emotions in Contemporary Neuroeconomics and Consumer Behaviour}

Until very recently, cognitive thinking has dominated consumer behaviour research. Bagozzi et al. (1992) take this approach in dealing with the theory of recent action. Janiszewski and Meyvis (2001) attempt to understand mere exposure (Zajonc, 1968) in terms of how it influences the processing fluency and formation of larger chunks of information, rather than as an immediate effect of affect. Also Barone et al. (2000), Shiv and Fedorikhin (1999), Luce (1998) and Duhachek (2005), focussing on how to cope with conflicts between positive and negative goals, basically attempt to understand how consumers solve emotional problems using cognitive information processing.

Even when more affective elements are introduced, they are seen in the light of cognitive choices. Pham et al. (2001) discuss feelings and choices in terms of judgemental properties of consciously administered feelings. Lee and Sternthal (1999) study mood as a factor influencing the stimulus-object relationship in the classical cognitive response formulation. Murry et al. (1992) attempt to understand how feelings for television programmes influence the evaluation of advertising, which in turn influences the evaluation of brands. Finally, Adaval (2003), in his discussion of affect in relation to 
brand evaluation, claims that affect influences the image of the brand and thereby is converted to a cognitive element.

Still, some authors during the past decade or two have increasingly concerned themselves with different aspects of affect. In early work, the terms feeling, emotions, moods, affect, etc. are used interchangeably. Erevelles (1998), however, emphasizes a distinction between feelings/emotions, mood, affective aspects of attitudes, and individual differences in affective behaviour. Here, as in most other research, feelings and emotions are used interchangeably and seen as affective reactions of short duration to stimuli in the environment or to internal imbalances. In contrast to this, mood is seen as a longer lasting, mostly weaker affective condition of the individual.

The study of feelings/emotions has a reasonably long tradition in psychology and social psychology. Different authors (Izard, 1977; Plutchik \& Kellerman, 1974; Frijda, 1986; Ekman, 1980) have proposed different listings of what they call primary, secondary and tertiary feelings - sometimes labelled emotions. Neither here nor in the consumer behaviour literature is any clear distinction between feelings and emotions found. Holbrook and Batra (1987) and Richins (1997) have reported listings of feelings/emotions of relevance for consumption behaviour. These authors see feelings/emotions as response patterns to different situations, and a basic issue has been whether such feelings/emotions are largely culturally influenced or exist in a consistent manner across different cultures and, thus, to a greater extent must be seen as inherited traits.

In dealing with different batteries of feeling questions, it is always possible to distinguish between positively and negatively loaded feeling words (Ortony \& Turner, 1990; Hansen, 2005). The positively loaded feelings/emotions are seen to control approaching behaviour, whereas the negatively loaded feelings/emotions are seen to govern avoidance behaviour.

The role of emotions as a fundamental physiological brain process guiding and influencing most individual choice behaviour, and certainly not least consumer choices, is becoming well documented. Here emotions are seen as fundamentally different from feelings. Emotions are elementary unconscious neurological processes, sometimes labelled somatic markers. Feelings are their cognitive counterparts. Basic research in this area has been reported by Le Doux (1998 and 2002) and Damasio (1994, 2000 and 2003). Using functional Magnetic Resonance Imaging (fMRI), they have shown how, so far largely overlooked, elementary behaviour controlling processes in the individual play an important role in consumers' everyday lives. The impact of such processes on consumer choices has been shown by McClure et al. (2004). Based on a fMRI experiment, they identified how emotions associated with a brand name may pop up in consumers' evaluation process. Each of four identical groups was asked to consume a cola drink and report on their experience of the consumption. One group was faced with a cola brand unknown to the respondents. The second group was faced with the same unknown cola brand but with a brand name attached to it. The third group was faced with Coca Cola without knowing the brand name and finally the fourth group was given Coca Cola with the brand name attached. Only in the last group were brain responses clearly identifiable as emotional response. The ability to respond emotionally to brands in this manner relies on inherited emotional response tendencies combined with guiding mechanisms (labelled by some authors as somatic markers) acquired through earlier experiences with the items that eventually give rise to emotional responses. Similar findings are reported by Deppe et al. (2005). 
Using fMRI or other brain scanning devices in consumer behaviour studies is, however, difficult. Costs per observation are extremely high, and the necessary equipment is limited and in most places dedicated to medical research. Therefore other ways of identifying emotional response are needed when one wishes to estimate such tendencies, as they are associated with different brands, products, company names, etc.

All these methodologies are cumbersome and expensive, however. Therefore attempts with interview-based measures have been vital for consumer behaviour research. Hansen (2005) argues that feeling words, when presented as stimuli to respondents in survey research, will tap the actual and unconscious emotional response to the specific object in question. The argument is that because conscious feelings are generated by unconscious emotional responses, then having respondents consciously scale such feeling words will in essence gauge the underlying - and unconscious - emotional responses that have given rise to the feelings. The issue is further discussed below. When such data from survey research are analysed using factor analysis, Hansen (2005) demonstrates that two underlying factors result, corresponding to approach and avoidance behaviour, or correspondingly to joy or sorrow, or any other positive/negative interpretation, completely in line with other research on basic emotional responses. In S-O-R terminology, where $\mathrm{S}$ denotes the stimulus, and $\mathrm{R}$ the response, and $\mathrm{O}$ represents the unknown intervening process (here emotions or somatic markers), inferences can be made about the process or rather the emotions by studying relating patterns of stimuli and responses. By computing a score for the positive items, an approach tendency can be estimated and, in a similar manner, a score quantifying the avoidance tendencies can be calculated; then by taking the difference between these two scores, a Net Emotional Response Strength (NERS) score can be computed (Hansen et al., 2006).

\section{Emotions in Political Science}

In today's political climate, much debate and speculation concerns how voters manage to decide on which candidate they want to support with their votes at elections. Since the expressions "spin" and "spin doctor" became household words in the political landscape, the public debate increasingly tends to see the media and the voters as creatures without volition who are led along by clever manipulators. The initial election success of Tony Blair in the UK has been judged by observers in the communication world as a product of clever manipulation - or spin - by his expert advisers, but this tendency to see spin as an important tool kit is by no means limited to the UK.

Classic theory on voting behaviour (Downs, 1957) sees such behaviour as a basically economic and rational process, whereby the voting individual weighs expectations as to utility income from the government and opposition actions in past and future periods to arrive at the "rationally" best voting alternative. Because the judgments underlying voting behaviour concern both the future - which is uncertain - and very complex matters in relation to which utility income is difficult to establish, the concept of ideology is introduced as one way for the voter to reduce such uncertainties to a level where rational decisions can be made. In later research, where voting behaviour is seen as a more social-cognitive process, the political landscape of increasing complexity still has to be reduced to a manageable substance through the use of judgment (Conover \& Feldman, 1986; Funk, 1999; Kinder, 1986; Lau, 1986; Lodge \& Stroh, 1993).

Caprara, Barbaranelli and Zimbardo (2002), in their study on voter perception of politicians, are also concerned with the way in which voters operate in the complex 
political environment. They point to the fact that many voters seem to deal with politicians in a basically very simplified fashion - particularly compared to the way in which they deal with themselves or celebrities.

These various attempts at explaining complex decisions - in the strict utility income maximizing sense of the voting decision - by introducing complexity-reducing mechanisms have a clear parallel in consumer behaviour research as it attempts to explain how consumers manage to decide on complex issues. Though choosing a brand of deodorant may seem a trivial decision, in theoretical principle it requires the same type of complexity reduction in order to make both the individual brand decision manageable and to enable the consumer to survive a day of myriad decisions on trivial issues.

Also in political science a growing concern with emotions is evident (Marcus \& Mackuen, 1993; Wolak et al., 2003; Marcus, 2003). Here, the most promising developments in contributing to our understanding of how individuals make decisions come from neuroscientific research into how the brain works. In this research, understanding the so-called emotional processes and the role of emotions in shaping human behaviour is key. The Somatic Marker Hypothesis (Bechara \& Damasio, 2005) sees the role of emotions as an unconscious process that controls responses to both known and unknown stimuli, based on an interpretation of the stimulus in relation to past experiences of a similar nature.

The Somatic Marker Hypothesis assumes that rational decision-making is actually preceded and supported by unconscious, emotional processes. It seems, based on the research (Bechara \& Damasio, 2005), that the individual's ability to make decisions that will be advantageous is largely explained by unconscious brain activity, where emotions are a factor guiding rational decision-making through unconscious simplification of a complex environment.

In McDermott (2004), the possible roles of emotions in political science are discussed. The author argues that political decision-making in many instances is characterized by lack of information and uncertainty about outcomes of alternate strategies, and therefore emotions possibly play a critically useful function as a foundation for swift and accurate decision-making.

Although the focus of the discussion is on the role of emotions in politicians' decision making, the parallel to citizens' voting behaviour is obvious. In an early study of voters' choice of feeling words associated with the political candidates, a two-factor model of emotions guiding the choice between Carter and Reagan is suggested. Here the two factors are orthogonal and reflect positive and negative affect. Results for Reagan are shown in Figure 1.

Similar findings are discussed by Marcus and Mackuen (1993). The two-dimensional structure of voters' emotional responses is very similar to that found in consumer behaviour studies and is discussed above as the Net Emotional Strength Score (NERS). Therefore, it is obvious that one should attempt to apply the NERS measurement technique to voting behaviour as well.

Based on the previous brief discussion, the present authors see an opportunity to study voting behaviour much as a marketing researcher would study consumer behaviour. The basic assumption is that rational decisions in both types of behaviour are guided by emotional processes that are unconscious in nature, but that enhance the individual's ability to make swift and advantageous decisions.

The purpose of the present paper is to attempt to contribute to a better understanding of voting behaviour by applying methods and models that are gaining recognition 
Figure 1. Factor Space of Seven Affect Used To Map Emotional Resonses to the 1980 Presidential Candidates (Marcus \& Mackuen 1993, page 675)
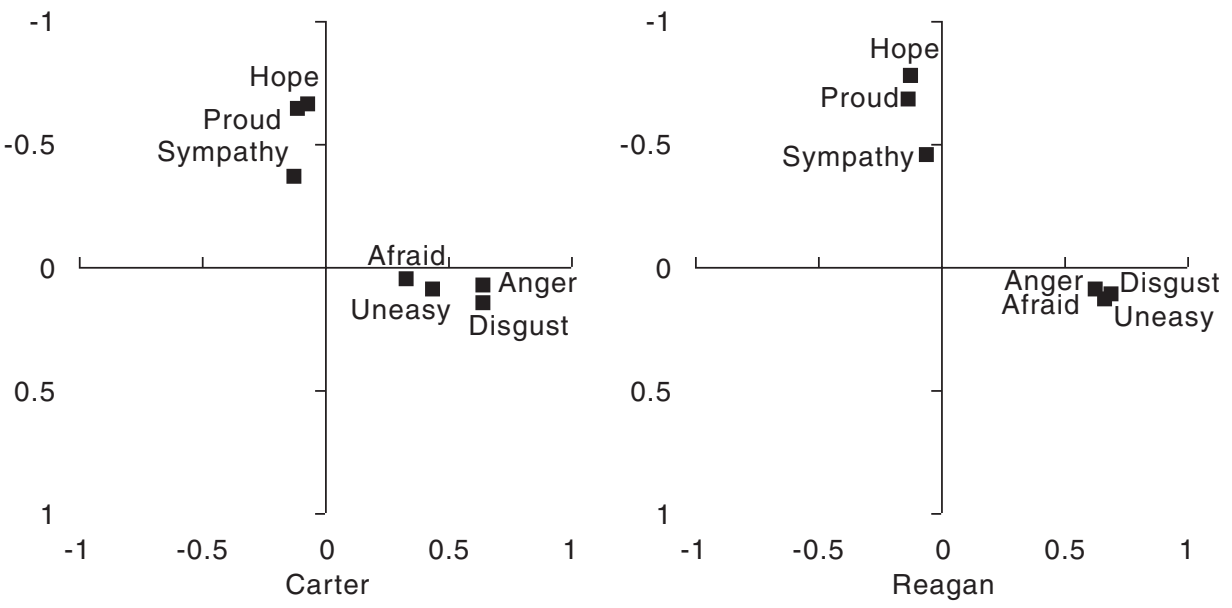

Source: 1980 ANES data.

Note: The figures represent a varimax rotation of a principal factor solution for the correlation matrix among the seven items for each candidate. The dimensionality of a factor space is not, of course, a simple statistical inference. Here, it appears that two dimensions capture the bulk of the common variance. The eigenvalues for Carter are 1.48, .74, and .14. For Reagan, the eigenvalues are 2.07, 1.03, and .35.

as important mechanisms in consumer behaviour research. This entails seeing the top political candidates much as one would see a brand and measuring the emotional response to individual candidates in order to explain their success or failure at the ballot box. And eventually to attempt to link the magnitude of such emotional response to the market share of the brands - the share of votes going to the individual candidate.

\section{Emotions and Feelings as Behavioural Control Mechanisms}

Emotions and more precisely emotional processes are seen by contemporary psychology and neuropsychology as mechanisms that control basic reactions such as glandular reactions: sweating in the palms, or autonomous reactions: increased heart rate to prepare the body for running. Basic reactions such as fear or freezing in the face of danger are also controlled by emotional processes residing in the oldest parts of the brain, the old cortex. A detailed description can be found in Damasio (2000), Goode (2002) and Franzen and Bouwman (2001) and is beyond the scope of this article.

In their elementary form, the emotional reactions can be seen as either an avoidance reaction: running away, retracting an arm or as an approach reaction: reaching out to grab, walking up to something. The original purpose of these reactions was basically to enable the individual to stay alive: Running away to avoid being eaten or running up to get something to eat!

The emotional processes reside in the limbic system, and they work in a direct fashion without involving the New Cortex, where deliberation and reflection take place. The emotional processes are unconscious in the sense that they do not involve reflection, but rather rely on previously stored information, which is used to classify the current stimulus so that the process will initiate the correct response: approach or avoid. 
The number of basic emotions has been discussed intensively by researchers (Izard, 1977; Ekman, 1980), as have the distinctions between primary and secondary emotions. To further complicate matters, other writers (Plutchik, 1980) have used the term emotion in the colloquial meaning of the word and therefore have identified a large number of different emotions. For our purpose, we see emotions as those unconscious processes described above, which in a behavioural sense are expressed in an approach reaction or an avoidance reaction. These two behavioural tendencies are mirrored in two basic emotions: joy and sorrow/sadness or simply a positive and a negative emotional response.

We label the detailed representation of these two emotions as feelings. Feelings are either unconscious, as the emotion, or they are consciously experienced - the individual feels happy or elated - and feelings may even be such that the individual can express them - "I am in love", "I feel depressed". Thus, when an emotion is aroused by a stimulus, it may give rise to an unconscious reaction or to a reaction accompanied by one or more feelings of which the individual is conscious.

To give an example of emotional response in a low-involvement and probably not very conscious situation, imagine the consumer in front of a supermarket shelf with brands of instant coffee. The stored emotional response potential from past experience and advertising will direct the consumer to brand choice in a split second - and probably without any deliberation or reflection whatsoever. Another consumer in the same supermarket may see a brand of marmalade that has been absent from the shelves for a long time. Here, the emotional response is so strong that it even gives rise to conscious feelings of happiness that the brand is available again, and the brand is chosen, this time after an emotional response that has a conscious representation.

When transferred to an election setting, the first example above may find its parallel in a voter who unflinchingly votes for the same party, election after election, irrespective of whether objective information should induce him to switch party allegiance. And the second example could find its parallel in a situation where a niche party develops a marked profile on one or two issues, leading the voter to switch party, owing to the possibility to line up with an issue that other parties did not see or express as clearly.

\section{Measuring Emotional Reactions and Responses}

As mentioned above, fMRI scanning is the state-of-the-art, scientifically justified way of registering the brain centres that are active in various decision or information processes. However, brain scanning - irrespective of technical solution - requires expensive and cumbersome machinery, and therefore other methods for measuring emotional responses that are better suited to consumer research problems and to research with larger, probability-based samples have to be developed and used.

The obvious solution is to apply self-reporting through questionnaire-based scales. Even though the emotional processes as such are unconscious in nature, they may well give rise to feelings that are either completely conscious or can be made conscious through probing questions. When the individual answers such questions about what feelings are relevant in a given decision situation and gives scaled answers to the strength with which the feelings are felt, then information about the underlying emotional responses can be inferred from these answers.

The methodology has been applied in a number of studies of consumers' reactions to brands, to design and to sponsorship arrangements and sponsoring companies (Hansen, 2005; Christensen, 2006; Desmet, 2003; Charlton-Jones, 2005; Lundsteen \& 
Hansen, 2006; Hansen \& Christensen, 2006) and has been applied in advertising testing, where the results have been compared to EEG scanning results with extremely good fit between the two sets of observations (Page, 2005; Kenning \& Plassmann, 2005).

The advantage of the questionnaire-based measurement over EEG, however, is that with scaled answers, the researcher not only can measure the strength of the emotional reaction, which is possible with EEG measurements as well, but also the direction of the reaction, which EEG scanning does not provide. Thus, using questionnaires, we can measure the amount of negative emotional reaction that a given brand or advertisement gives rise to and compare it with the amount of positive emotional reaction. Both reactions are important, as many products, such as insurance policies, give rise to negative reactions concerning the potential damage that the individual is trying to avoid by taking the insurance - whilst at the same time giving rise to positive reactions because the insurance policy purportedly should do something about it.

When measuring reactions to charitable institutions, it has been found (Hansen et al., 2006; Christensen, 2006) that the negative reactions in most instances actually are larger than the positive emotional reactions, precisely because the cause in itself - prevention of cancer, food for hungry children, medical aid in the third world - touches most individuals in a negative way, which overshadows the positive emotions generated by the fact that the individual charity collects money to do something about the problems.

When the measured negative emotional reaction is subtracted from the measured positive emotional reaction, one number appears, which we have labelled Net Emotional

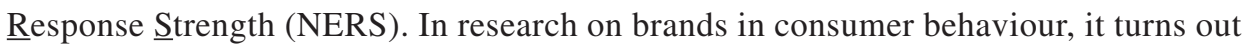
that the size of NERS is relatively well correlated with the standing of the brand, that is, the more well known and popular a brand is, the higher its corresponding NERS. Moreover, it has been shown that the more loyal an individual is to a brand, the higher the corresponding NERS - and even non-users of a brand, who are likely to switch to the brand, should the occasion arise, elicit a high NERS.

\section{Measurement of Emotional Reactions to Top Politicians}

Given the previous arguments presented here, it seems obvious to employ measurement of emotional responses to politicians in order to understand voter behaviour. It has been argued above that much voter behaviour seems to resemble the behaviour that is well documented when consumers choose between brands, that is: basing the actual choice on experience of an emotional nature and making emotionally controlled choices. And should the voter try to obtain an overview of the factual content of a given political issue, the amount of conflict would probably overwhelm most voters' cognitive abilities.

The methodology employed is the same as that employed when measuring emotional responses to brands and advertising:

- The respondent is presented with a number of feeling words - in this case 12,6 positive and 6 negative - that may be used to describe a given politician

- The respondent selects those words out of the 12 that are appropriate for the given individual and the politician in question and scales - on a 7-point scale - those words to describe the extent to which they fit the politician in question (from 'not at all' to 'very well')

- The process is repeated for the other politicians in the study. 
The data are subjected to a factor analysis - principal components with a varimax rotated solution - to isolate the two basic emotional response tendencies: positive emotional response and negative emotional response. Based on the rotated factor loading matrix, nonstandardized and non-normalized factor scores are computed. These factor scores represent the strength of the positive vs. negative emotional responses for each individual respondent. The principle underlying the computations is illustrated in Table 1 below.

Table 1. Example of Calculation of Positive and Negative Emotional Response and NERS for one Respondent

\begin{tabular}{|c|c|c|c|c|c|c|}
\hline $\begin{array}{l}\text { Emotional } \\
\text { Statement }\end{array}$ & $\begin{array}{c}\text { Answer } \\
\text { (on a 7-point } \\
\text { Likert scale) } \\
\text { a }\end{array}$ & $\begin{array}{c}\text { Factor }^{*} \\
\text { Loading } \\
+ \text { Emotions } \\
\mathrm{b}\end{array}$ & $\begin{array}{c}\text { Positive Score } \\
\text { (answer* } \\
\text { Loading) } \\
a^{*} b\end{array}$ & $\begin{array}{l}\text { Factor }^{*} \\
\text { Loading } \\
\text {-Emotion } \\
\text { c }\end{array}$ & $\begin{array}{c}\text { Negative } \\
\text { Score } \\
a{ }^{*} \mathrm{c}\end{array}$ & $\begin{array}{c}\text { NERS } \\
\text { (Pos. Score } \\
\text { - Neg. Score) }\end{array}$ \\
\hline Desire & 2 & 0.59 & 1.17 & 0.00 & 0.01 & \\
\hline Stimulating & 3 & 0.74 & 2.21 & 0.02 & 0.06 & \\
\hline Happy & 0 & 0.90 & 0 & 0.00 & 0 & \\
\hline Fine & 6 & 0.68 & 4.08 & -0.03 & -0.02 & \\
\hline Fresh & 4 & 0.75 & 3.01 & -0.04 & -0.02 & \\
\hline Pretty & 2 & 0.82 & 1.64 & 0.01 & 0.02 & \\
\hline Critical & 0 & -0.01 & 0 & 0.75 & 0 & \\
\hline Doubt & 0 & -0.02 & 0 & 0.72 & 0 & \\
\hline Worry & 5 & 0.01 & 0.04 & 0.54 & 2.70 & \\
\hline Irritating & 2 & -0.01 & -0.03 & 0.90 & 0.18 & \\
\hline Total & & & 12.12 & & 2.93 & 9.20 \\
\hline
\end{tabular}

* From forced two-factor unimax related factor analytical solution

The example contains 10 feeling words that this respondent has selected. In the Answer column, the scaling answers to the individual feeling words are shown. The column labelled Factor Loading +Emotions contains the results of the principal components analysis after varimax rotation and the loadings show the correlation between the individual feeling words and the positive factor. The next column contains the calculation of the positive emotional response (Answer * Loading, summed across all variables), which for this respondent is 12.12 . The following columns contain the same information, only resulting in the negative score of 2.93. The resulting NERS for this respondent is $(12.22-2.93) 9.20$.

\section{The Study}

The actual study of emotional reactions to top politicians took place in connection with the latest general election in Denmark in the fall of 2005. tns/Gallup kindly carried out the actual data collection as part of their ongoing measurement of political sentiment in connection with the election.

Data were collected three weeks before the general election and again immediately after the election was carried out - enabling analysis of changes during the election campaign and correlating these changes with the actual outcome of the election. Data were collected as part of tns/Gallup's CATI omnibus with a sample of 1000 persons, representative of the adult Danish population, 13 years of age and above. Two omnibus rounds were used for the study. Fieldwork was carried out in January and February 2005. 
The scope of the study had to be limited, as it was carried out as an add-on to a political questionnaire probing the respondents' knowledge of political issues at stake in the election campaign. It was decided to limit the scope by only measuring emotional responses to the 6 best-known and most highly profiled political candidates. These candidates were all party leaders of their individual parties as follows:

- Anders Fogh Rasmussen, incumbent prime minister and leader of Venstre, the largest liberal party

- Mogens Lykketoft, leader of the opposition and leader of the Social Democratic Party, the largest left wing party

- Bendt Bendtsen, minister of economy and business and leader of the Conservative People's Party, part of the government coalition and a liberal party to the right of Venstre

- Marianne Jelved, leader of Radikale, a small, liberal party by tradition linked to the Social Democrats because of its standpoint on social issues

- Holger K. Nielsen, leader of Socialist People's Party, to the left of the Social Democratic Party, by tradition having a strong following amongst employees in the public sector, also in the upper echelons, because of its' strong socialist standpoint appealing to left wing intellectuals

- Pia Kjærsgaard, leader of Danish People's Party, a right-wing populist party, originating in the tax protest party of the 70's, now appealing to an older electorate because of its strong standpoint on issues of refugee integration and public spending on issues concerning the elderly

\section{Hypotheses}

Politicians are not universally well known and established. Moreover, due to their political standpoint in relation to the voter and the voter's prior experience, emotional responses to top politicians should vary, exemplifying that the voting public have varying emotional responses to them. Thus:

1. H1: Emotional responses elicited by the 6 politicians in the study should vary in the pre-election measurement reflecting their standing in the upcoming election - as measured by their position in parliament

It seems reasonable to assume that the emotional responses of the individual politician's loyal followers - respondents who are inclined to vote for the party of which he/she is the leader - will be more positive than those of voters intending to vote for other parties. Thus:

2. H2: Emotional responses to any politician studied should be more favourable amongst respondents intending to vote for his/her party than amongst all other voters

The emotional responses measured after the election will contain two types of information:

- The same type of difference in response between actual voters and non-voters for any given politician that is hypothesized in $\mathrm{H} 2$ 
- A reaction to the actual outcome of the election - an emotional experience modifying the response - depending on whether the party did well or less well in the election

Given that the measurement consists of one measurement, it will not be possible to separate the two effects. However, it still seems reasonable to hypothesize that:

3. H3a: Emotional responses to politicians whose election results are seen as being fair or good will show no change or a positive change after the election

$\mathrm{H} 3 \mathrm{~b}$ : Emotional responses to politicians whose election results are seen as being negative will show a negative change after the election

\section{Results}

In Table 2 the overall election results in 2001 - the previous general election - and 2005 are shown. The percentages of votes and the corresponding changes are shown in the table.

Table 2. Results from the Latest Two General Elections in Denmark, 2001 and 2005

\begin{tabular}{|c|c|c|c|c|c|c|}
\hline $\begin{array}{l}\text { Parties' } \\
\text { percentage } \\
\text { share of all vote }\end{array}$ & $\begin{array}{l}\text { Venstre/ } \\
\text { Liberal } \\
\text { es Party }\end{array}$ & $\begin{array}{c}\text { Social } \\
\text { Democrats }\end{array}$ & $\begin{array}{c}\text { Conservative } \\
\text { People's } \\
\text { Party }\end{array}$ & $\begin{array}{l}\text { Radical } \\
\text { Party }\end{array}$ & $\begin{array}{c}\text { Danish } \\
\text { People's } \\
\text { Party }\end{array}$ & $\begin{array}{c}\text { Socialist } \\
\text { People's } \\
\text { Party }\end{array}$ \\
\hline Party leader & $\begin{array}{c}\text { Anders Fogh } \\
\text { Rasmussen }\end{array}$ & $\begin{array}{c}\text { Mogens } \\
\text { Lykketoft }\end{array}$ & $\begin{array}{c}\text { Bendt } \\
\text { Bendtsen }\end{array}$ & $\begin{array}{l}\text { Marianne } \\
\text { Jelved }\end{array}$ & $\begin{array}{c}\text { Pia } \\
\text { Kjærsgaard }\end{array}$ & $\begin{array}{c}\text { Holger K. } \\
\text { Nielsen }\end{array}$ \\
\hline 2001 & $31.2 \%$ & $29.1 \%$ & $9.1 \%$ & $5.2 \%$ & $12.0 \%$ & $6.4 \%$ \\
\hline 2005 & $29.0 \%$ & $25.8 \%$ & $10.3 \%$ & $9.2 \%$ & $13.3 \%$ & $6.0 \%$ \\
\hline Change & $-7.1 \%$ & $-11.3 \%$ & $13.2 \%$ & $76.9 \%$ & $10.8 \%$ & $-6.3 \%$ \\
\hline Comment & Satisfactory & Unsatisfactory & Very good & Extremely good & Very good & Unsatisfactory \\
\hline
\end{tabular}

The numbers from the election speak for themselves, still for purposes of later analysis, a few comments are warranted.

In the last row, a general "election watcher expert's" view on the outcome is added. Venstre, the Liberals, had a loss of votes, however the party kept the position gained in 2001 as Denmark's largest party, which was seen as satisfactory, as the election in 2001 was extremely good. The Social Democrats lost votes again in 2005, continuing a downward trend in voter appeal, which was seen as unsatisfactory for this party, which used to be the undisputedly largest party in Danish politics. The Conservative gain was very good given that the party had been on a downturn over the previous two elections. Radikale's gain of more than $75 \%$ was seen as an extremely good comeback for this party, which was severely reduced in the 2001 election. The two People's parties show opposite trends: Danish People's party continue their upward trend, whilst Socialist People's party continue on a downward trend, possibly because their left-wing intellectual followers are switching to Radikale.

The emotional responses towards the 6 party leaders are summarized in Table 3 below.

When the two series of ranks are compared, Spearman's rank order correlation is as low as 0.1429 , confirming that $\mathrm{H} 1$ is not supported. The critical value of $r_{s}$ to compare with at the .05 level of significance is 0.89 , so the correlation is clearly not statistically significant - which holds true for all subsequent coefficients computed. 
Table 3. NERS Towards 6 Top Politicians, 2005 election (measured three weeks before the actual election)

\begin{tabular}{|c|c|c|c|c|c|c|}
\hline & $\begin{array}{l}\text { Venstre/ } \\
\text { Liberal Party: } \\
\text { Anders Fogh } \\
\text { Rasmussen }\end{array}$ & $\begin{array}{l}\text { Social } \\
\text { Democrats: } \\
\text { Mogens } \\
\text { Lykketoft }\end{array}$ & $\begin{array}{l}\text { Conservative } \\
\text { People's } \\
\text { Party: } \\
\text { Bendt } \\
\text { Bendtsen }\end{array}$ & $\begin{array}{l}\text { Radical } \\
\text { Party: } \\
\text { Marianne } \\
\text { Jelved }\end{array}$ & $\begin{array}{l}\text { Danish } \\
\text { People's } \\
\text { Party: } \\
\text { Pia } \\
\text { Kjærsgaard }\end{array}$ & $\begin{array}{l}\text { Socialist } \\
\text { People's } \\
\text { Party: } \\
\text { Holger K. } \\
\text { Nielsen }\end{array}$ \\
\hline $\begin{array}{l}\text { All voters, } \\
\text { NERS scores }\end{array}$ & 4.73 & -0.47 & 2.56 & 0.66 & -1.91 & 0.75 \\
\hline $\begin{array}{l}\text { Share of votes, } \\
2001 \text { election }\end{array}$ & 31.2 & 29.1 & 9.1 & 5.2 & 12.0 & 6.4 \\
\hline Rank NERS & 1 & 5 & 2 & 4 & 6 & 3 \\
\hline Rank votes 2001 & 1 & 2 & 4 & 6 & 3 & 5 \\
\hline Rank votes 2005 & 1 & 2 & 4 & 5 & 3 & 6 \\
\hline
\end{tabular}

However, one might argue that $\mathrm{H} 1$ does not take into account that, at the time of measurement, 3 weeks before the election, the NERS scores will probably already have begun reflecting what is going to happen at the upcoming election. When the rank order correlation is calculated comparing NERS score ranks with vote ranks in the 2005 election, it comes out at 0.4857 , which is a definite improvement.

Thus, the raw NERS scores do not directly reflect the standing of the individual politicians in the election. An important explanation for this may well be that various politicians - just like consumer brands - may appeal very differently to different segments of voters. $\mathrm{H} 2$ states that we expect higher NERS scores amongst loyal voters than amongst non-voters, and the hypotheses thus will contribute with an explanation of the overall NERS score composition.

Table 4. NERS Scores Amongst Loyals (intending to vote for) and Non-loyals, 2005 Election (measured three weeks before the actual election)

\begin{tabular}{|c|c|c|c|c|c|c|}
\hline & $\begin{array}{l}\text { Venstre/ } \\
\text { Liberal Party: } \\
\text { Anders Fogh } \\
\text { Rasmussen }\end{array}$ & $\begin{array}{l}\text { Social } \\
\text { Democrats: } \\
\text { Mogens } \\
\text { Lykketoft }\end{array}$ & $\begin{array}{l}\text { Conservative } \\
\text { People's } \\
\text { Party: } \\
\text { Bendt } \\
\text { Bendtsen }\end{array}$ & $\begin{array}{l}\text { Radical } \\
\text { Party: } \\
\text { Marianne } \\
\text { Jelved }\end{array}$ & $\begin{array}{l}\text { Danish } \\
\text { People's } \\
\text { Party: } \\
\text { Pia } \\
\text { Kjærsgaard }\end{array}$ & $\begin{array}{l}\text { Socialist } \\
\text { People's } \\
\text { Party: } \\
\text { Holger K. } \\
\text { Nielsen }\end{array}$ \\
\hline NERS loyals & 13.5 & 5.7 & 8.44 & 7.67 & 11.53 & 7.29 \\
\hline NERS non-loyals & 1.44 & -2.08 & 2.56 & -0.13 & -2.77 & 0.28 \\
\hline Rank loyals & 1 & 6 & 3 & 4 & 2 & 5 \\
\hline Rank votes 2001 & 1 & 2 & 4 & 6 & 3 & 5 \\
\hline Rank votes 2005 & 1 & 2 & 4 & 5 & 3 & 6 \\
\hline
\end{tabular}

Spearman rank order correlations between NERS ranks amongst loyals and vote ranks: $\mathrm{r}_{\mathrm{s}(2001)}=0.3714 ; \mathrm{r}_{\mathrm{s}(2005)}$ $=0.4286$

When comparing the two first rows of Table 4, it is obvious that NERS amongst respondents that report an intention to vote for the party leader's party is much higher than amongst respondents intending to vote for another party. Thus $\mathrm{H} 2$ is confirmed.

Further to the discussion under H1, it is obvious that the low NERS associated with Pia Kjærsgaard (Danish People's Party) - and one in contrast to her following at the election - is due to a negative NERS amongst non-loyals. Her party line is very divisive: It appeals strongly to a reactionary, change-averse and typically elderly voter with 
very traditional values and is strongly rejected by the more modern and tolerant voters - a strange combination of a mixed individualistic/collectivistic income distribution policy and traditional values policy. A similar structure is apparent for Mogens Lykketoft (Social Democrats), the lack-lustre leader of the former largest party, organizing the traditional factory workers, of whom very few are left in Denmark. Also Marianne Jelved (Radical Party) has this type of strong appeal and rejection, reflecting this party's combination of collectivist income distribution policy and modern values policy.

As a further comment on H1, Spearman rank order correlations have been calculated on the NERS ranks amongst own voters compared to election results. This improves the correlation between the 2001 election results and the NERS amongst loyals to 0.3714 from 0.1429 . When the correlation is computed with the 2005 election results, the coefficient is 0.4286 , more or less the same value that was obtained when correlating NERS ranks amongst all voters and 2005 election results. The increase in the rank order correlation also confirms the ability of the emotional responses to predict - to some extent - the outcome of the election, however, other factors - such as loyalty to a party, knowledge of the actual policies of the various parties and politicians - play at least an equally large role.

So far we have only analysed the "pre-election" measurements. In Table 5, we show the raw results of the post-election measurements.

Table 5. NERS Scores Post-election, 2005 Election (measured 1 week after election)

\begin{tabular}{|c|c|c|c|c|c|c|}
\hline & $\begin{array}{l}\text { Venstre/ } \\
\text { Liberal Party: } \\
\text { Anders Fogh } \\
\text { Rasmussen }\end{array}$ & $\begin{array}{l}\text { Social } \\
\text { Democrats: } \\
\text { Mogens } \\
\text { Lykketoft }\end{array}$ & $\begin{array}{l}\text { Conservative } \\
\text { People's } \\
\text { Party: } \\
\text { Bendt } \\
\text { Bendtsen }\end{array}$ & $\begin{array}{l}\text { Radical } \\
\text { Party: } \\
\text { Marianne } \\
\text { Jelved }\end{array}$ & $\begin{array}{l}\text { Danish } \\
\text { People's } \\
\text { Party: } \\
\text { Pia } \\
\text { Kjærsgaard }\end{array}$ & $\begin{array}{l}\text { Socialist } \\
\text { People's } \\
\text { Party: } \\
\text { Holger K. } \\
\text { Nielsen }\end{array}$ \\
\hline $\begin{array}{l}\text { NERS score, } \\
\text { all voters }\end{array}$ & 4.09 & -0.17 & 2.74 & 1.35 & -1.29 & 0.44 \\
\hline $\begin{array}{l}\text { NERS score, } \\
\text { loyals }\end{array}$ & 12.18 & 3.56 & 6.76 & 8.46 & 9.68 & 4.82 \\
\hline $\begin{array}{l}\text { NERS score, } \\
\text { non-loyals }\end{array}$ & 1.35 & -1.08 & 2.04 & 0.29 & -2.11 & 0.04 \\
\hline
\end{tabular}

The overall structure of the results is similar to that of the pre-election measurements: Three of the leaders show NERS scores that are positive, two exhibit negative NERS scores amongst all voters and the last, Holger K. Nielsen (Socialist People's Party), a NERS score close to zero.

The $\mathrm{H} 2$ assumption, that respondents who actually voted for the party of the various party leaders have a higher NERS score than those who chose to vote for other parties, is very obvious, again particularly Pia Kjærsgaard of Danish People's Party exhibits a marked strong appeal/strong rejection profile, but also Mogens Lykketoft of the Social Democratic Party exhibits that profile - with the lowest NERS score amongst the loyals demonstrating the lukewarm appeal he had in the election.

Concerning $\mathrm{H} 3 \mathrm{a}$ and $\mathrm{H} 3 \mathrm{~b}$, the changes in NERS scores pre- and post-election are tabulated in Table 6 below.

When interpreting the numbers, it is important to remember that they are taken from two different samples as a time series survey, using the same variables for questioning - so smaller differences should be expected than when looking at data taken from the same population pre- and post-election. In the concrete case, we do not have access to 
the switching matrix where we can study the actual movements from intended voting to actual voting and what levels of NERS may have driven the voters away from or towards a given candidate.

Table 6. Changes in NERS Scores Pre- and Post-election, 2005 Election (measured 3 weeks before and 1 week after the election)

\begin{tabular}{|c|c|c|c|c|c|c|}
\hline & $\begin{array}{l}\text { Venstre/ } \\
\text { Liberal Party: } \\
\text { Anders Fogh } \\
\text { Rasmussen }\end{array}$ & $\begin{array}{l}\text { Social } \\
\text { Democrats: } \\
\text { Mogens } \\
\text { Lykketoft }\end{array}$ & $\begin{array}{l}\text { Conservative } \\
\text { People's } \\
\text { Party: } \\
\text { Bendt } \\
\text { Bendtsen }\end{array}$ & $\begin{array}{l}\text { Radical } \\
\text { Party: } \\
\text { Marianne } \\
\text { Jelved }\end{array}$ & $\begin{array}{l}\text { Danish } \\
\text { People's } \\
\text { Party: } \\
\text { Pia } \\
\text { Kjærsgaard }\end{array}$ & $\begin{array}{l}\text { Socialist } \\
\text { People's } \\
\text { Party: } \\
\text { Holger K. } \\
\text { Nielsen }\end{array}$ \\
\hline All voters & -0.63 & 0.29 & 0.18 & 0.69 & 0.62 & -0.31 \\
\hline Pre and post loyals & -1.32 & -2.14 & -1.67 & 0.78 & -1.85 & -2.47 \\
\hline $\begin{array}{l}\text { Pre and post } \\
\text { non loyals }\end{array}$ & -0.09 & 1.00 & 0.32 & 0.42 & 0.66 & -0.24 \\
\hline $\begin{array}{l}\text { Expert comment } \\
\text { on election quality }\end{array}$ & $\begin{array}{l}\text { Satis- } \\
\text { factory }\end{array}$ & $\begin{array}{l}\text { Unsatis- } \\
\text { factory }\end{array}$ & $\begin{array}{l}\text { Very } \\
\text { good }\end{array}$ & $\begin{array}{l}\text { Extremely } \\
\text { good }\end{array}$ & $\begin{array}{l}\text { Very } \\
\text { good }\end{array}$ & $\begin{array}{l}\text { Unsatis- } \\
\text { factory }\end{array}$ \\
\hline
\end{tabular}

Numbers in bold denote significant differences, $\mathrm{p}>0.05$

When interpreting the numbers, it is important to remember that they are taken from two different samples as a time series survey, using the same variables for questioning - so smaller differences should be expected than when looking at data taken from the same population pre- and post-election. In the concrete case, we do not have access to the switching matrix where we can study the actual movements from intended voting to actual voting and what levels of NERS may have driven the voters away from or towards a given candidate.

With this in mind, we can observe that as far as all voters are concerned, no significant changes in NERS scores appear when we compare NERS scores amongst the loyal intenders and those who actually voted for the given candidate. This gives rise to two interesting observations:

- One is, that actually very little happens in the way of reaction to the various candidates as the election campaign progresses, which corroborates the idea that voting behaviour is a variation on the theme: low involvement consumer behaviour with low attention to communication and little processing of messages.

- The other is, that because the two samples are independent, the results can be interpreted as an indication of the fact that a certain threshold level of NERS is necessary and sufficient for a voter to decide on a given candidate in combination with what other information the voter may have concerning the favourite candidate, his/her policies, those of his/her party and those of other candidates and parties.

The data for the non-loyals, that is a comparison of average NERS scores in the group that did not intend to vote for the given candidate and the group that actually did not vote for him, show the same picture, that is, NERS scores elicited by the candidates that the voter has no preference for remain constant. This further confirms the comment above that not much seems to happen to voters during the election campaign when it comes to influencing them with communication concerning the candidates' and parties' policies and points-of-view. 
If the data had been collected as panel data, we would have had access to the switching matrix and the changes in NERS could have been used as independent variables in an attempt to predict voter choice. Because that is not the case, no such analysis can be carried out.

In the cases where the expert judgment after the election was that the candidate had a satisfactory, very good or extremely good election, no significant changes in NERS occur when we concentrate on the NERS score comparison between the two groups of loyals pre- and post-election.

So H3A, which states that we would expect a neutral to positive change in NERS elicited by the "winners", is partly corroborated - in spite of Jelved's extremely good election, no increase in NERS is seen, which would have been the reasonable development to expect, given that emotional response is affected also by the outcome of the election.

Concerning H3B, which states that the "election losers" will give rise to a negative change in NERS scores, both Lykketoft and Nielsen exhibit precisely that development amongst their loyal voters. As stated earlier, this can be interpreted in two ways, or rather as a combination of two effects:

- The decreasing NERS is in part attributable to the fact that their loyal voters are losing interest in the candidates - for any number or set of reasons

- The tendency towards a decreasing NERS is accelerated by the fact that they are both seen as at least partly responsible for their parties' lacklustre performance after the election.

Whatever the balance between the two reasons - which cannot be separated with the present design - the hypothesis is confirmed.

\section{Implications}

The findings give rise to a number of implications for political marketers trying to impress the voters with their candidacy and their points-of-view:

- Media selection: Because the situation for both loyal and non-loyal voters seems to be the same: Low involvement and low attention, the traditional marketing tools employed by candidates: Posters with a picture of the candidate and his party affiliation seem ill suited. This type of minimal information content, combined with a media vehicle as unobtrusive as a small poster hanging together with 3 or 4 similar posters in a lamp post, seems to be the least optimal choice if the purpose is to "break through" the voters' low involvement and lack of attention. An FMCG marketer faced with a similar situation would probably come to the conclusion that media such as TV would be more likely to make a greater impression - or even that an integrated marketing approach using various media in coordination to serve different purposes would be more optimal.

- Message selection: Again, given the low involvement and low attention nature of the voter, it is of paramount importance that the messages intended to impress voters in a positive way be selected so that they:

- Do not require extensive cognitive processing - as such processing is highly unlikely 
- Are easily recognizable and securely connected to the candidate in question as the campaign moves forward - because they have to register "in the correct compartment" in implicit memory, as they are perceived at the fringe of consciousness and attention

- Are repeated across all media apertures that are used to touch voters - the more low involvement and low attention media are used in the campaign, the higher the number of repetitions are needed for just parts of the message complex to register.

- Timing selection: Usual recommendations for communication under conditions of low involvement and low attention should be adhered to:

- Continuity is important, maintaining a presence during the whole of the campaign

- Recency is important, ensuring that voters are exposed to the core messages as close to the actual voting action as possible, as those voters who have not already made up their minds will be more open to information to support their decision at that time.

The final implication is related to methodology. As mentioned, the present study was carried out as survey research in a time series. Although this is good enough for tracking NERS amongst loyals and changes in levels of NERS, it does not provide enough documentation for the predictive power of emotional responses in combination with other factors, such as prior voting behaviour, perceived quality and relevance of political messages, etc. The optimal research design to improve on our understanding of how emotional processes drive voter behaviour would be to establish the measurements as part of a panel measurement of individuals' intention to vote. Such a research method would provide us with the party switching matrix and would therefore lend itself to statistical analysis of what drives voter behaviour.

\section{Note}

1. Damasio expresses this phenomenon as: a feeling of an emotion, an experience of a feeling of an emotion, an expression of an experience of a feeling (Damasio, 2000).

\section{References}

Adaval, R. (2003) How Good Gets Better and Bad Gets Worse: Understanding the Impact of Affect on Evaluations of Known Brands, Journal of Consumer Research, 30(3), Dec.

Bagozzi, R.P., Baumgartner, H \& YI, Y. (1992) State versus Action Orientation and the Theory of Reasoned Action: An Application to Coupon Usage, Journal of Consumer Research, 18(4), Mar.

Barone, M.J., Miniard, P.W. \& Romeo, J.B. (2000) The Influence of Positive Mood on Brand Extension Evaluations, Journal of Consumer Research, 26(4), Mar.

Bechara, A and A. Damasio (2005) The Somatic Marker Hypothesis: A Neutral Theory of Economic Decision Making, Games and Economic Behavior, 52(2), August.

Caprara, G.V., Claudio Barbaranelli and Philip G. Zimbardo (2002) When Parsimony Subdues Distinctiveness: Simplified Public Perceptions of Politicians Personality; Political Psychology 23(1)

Charlton-Jones, J. (2005) Capturing Emotions in Advertising and Benefiting from the Knowledge, Proceedings from the 2005 European Advertising Effectiveness Symposium, Budapest, June.

Christensen, Sverre Riis (2006) Measuring Consumer Reactions to Sponsoring Partnerships Based upon Emotional and Attitudinal Responses; International Journal of Market Research, 48(1).

Conover, P.J. and S. Feldmann (1986) The Role of Inference in the Perception of Political Candidates; in Political cognition, $19^{\text {th }}$ annual Carnegie Symposium on Cognition.

Damasio, A. (1994) Descartes Error: Emotion, Reason, and the Human Brain, Grosset/Putnam, New York. Damasio, A. (2000) The Feelings of what Happens. London: Vintage. 
Damasio, A. (2003) Looking for Spinoza: Joy, Sorrow, and the Feeling Brain. Harcourt.

Deppe, M., Schwindt, W., Kugel, H., Plassman, H \& Kenning, P. (2005) Nonlinear Responses Within the Medial Prefrontal Cortex Reveal When Specific Implicit Information Influences Economic Decision Making, Journal of Neuroimaging, 15, pp. 171-182.

Desmet, P.M.A. (2003) Measuring Emotions, in: Blythe, M.A., Monk, A.F., Overbeeke, K. \& Wright, P.C. (Eds.): Funology: From Usability to Enjoyment. Dordrecht: Kluwer Academic Publishers, pp. 111123.

Downs, A. (1957) An Economic Theory of Democracy. Harper \& Row.

Duhachek, A. (2005) Coping: A Multidimensional, Hierarchical Framework of Responses to Stressful Consumption Episodes, Journal of Consumer Research, 32(1), June.

DuPlessis, E. (2005) The Advertised Mind. Kogan Page.

Ekman, P. (1980) Biological and Cultural Contributions to Body and Facial Movement in the Expression of Emotions, in: RORTY, A.O.(Ed) Explaining Emotions. Berkeley: University of California Press.

Erevelles, S. (1998) The Role of Affect in Marketing, Journal of Business Research, 42, pp. 199-215.

Franzen, G. and M. Bouwman (2001) The Mental World of Brands. Reading: ACR.

Frijda, N.H. (1986) The Emotions. Cambridge: Cambridge University Press.

Funk, C.L. (1999) Bringing the Candidate into Models of Candidate Evaluation, Journal of Politics, 61.

Goode, Alistair (2002) The Value of Implicit Memory. Admap, December.

Hansen, Flemming (2005) Distinguishing between Feelings and Emotions in Understanding Communication Effects; Journal of Business Research, 58.

Hansen, Flemming and Sverre Riis Christensen (2006) Emotions in Consumer Choice and Advertising Theory and Findings Supporting it; Putnam and Sons, 2006 (to appear).

Hansen, Flemming, Anne Martensen and Sverre Riis Christensen (2006) Modelling Emotional and Attitudinal Responses as Drivers of Sponsorship Value; International Journal of Sponsorship and Sports Marketing, 7(1).

Holbrook, M.B. \& Batra, R. (1987) Assessing the Role of Emotions as Mediators of Consumer Responses to Advertising, The Journal of Consumer Research, 14(3), Dec., pp. 404-420.

Izard, C.E. (1977) Human Emotions. New York, Plenum Press.

Janiszewski, C. \& Meyvis (2001) Effects of Brand Logo Complexity, Repetition, and Spacing on Processing Fluency and Judgment, 28.

Kenning, P. \& Plassmann H. (2005) NeuroEconomics: An Overview from an Economic Perspective, Brain Research Bulletin, 67, pp. 343-354.

Kinder, D.R. (1986) Presidential Character Revisited; in Political Cognition, $19^{\text {th }}$ annual Carnegie Symposium on Cognition.

Lau, R.R. (1986) Political Schemata, Candidate Evaluations and Voting Behavior; in Political cognition, $19^{\text {th }}$ annual Carnegie Symposium on Cognition.

LeDoux, J. (1998) The Emotional Brain. New York: Phoenix.

LeDoux, J. (2002) Synaptic Self: How Our Brains Become Who We Are. New York: Viking.

Lee, A.Y. \& Sternthal B. (1999) The Effects of Positive Mood on Memory, Journal of Consumer Research, 26(2), Sep.

Lodge, M. and P. Stroh (1993) Inside the Mental Voting Booth: An Impression-Driven Process Model of Candidate Evaluation; in Explorations in Political Psychology.

Luce, M.F. (1998) Choosing to Avoid: Coping with Negatively Emotion-Laden Consumer Decisions, Journal of Consumer Research, 24(4), March.

Lundsteen, S. \& Hansen F. (2006) Tracking Shifts in Emotional Responses to Brands a Comparison of Two Studies; Proceedings from The $5^{\text {th }}$ International Conference On Research In Advertising (ICORIA) Bath.

Marcus, George E. (2003) The Psychology of Emotion and Politics; in Leoni Huddy, David Sears, and Robert Jervis: Oxford Handbook of Political Psychology. Oxford: Oxford University Press.

Marcus, George E. \& Mackuen, Michael B. (1993) Anxiety, Enthusiasm, and the Vote: The Emotional Underpinnings of Learning and Involvement During Presidential Campaigns, The American Political Science Review, 87(3), September pp. 672-685.

Martensen, Anne, Flemming Hansen and Sverre Riis Christensen (2005) Modelling Emotional and Attitudinal Responses as Drivers of Sponsorship Value; proceedings of EMAC.

McClure, S. M., J. Li, D. Tomilin, K:S. Cypert, L.M. Montague and P.R. Montague (2004) Neural Correlates of Behavioral Preference for Culturally Familiar Drinks, Neuron, 44, October.

McDermott, R. (2004) The Feeling of Rationality: The Meaning of Neuroscientific, Advances for Political Science, Perspectives on Politics, 2(4), December. 
Murry, J.P., Lastovicka, J.L. \& Singh, S.N. (1992) Feeling and Liking Responses to Television Programs: An Examination of Two Explanations for Media-Context Effects, Journal of Consumer Research, 18(4) Mar.

Ortony, A. \& Turner T.J. (1990) What's Basic about Basic Emotions? Psychological Review, 97, pp. 313.

Page, Graham (2005) The challenges for neuroscience in ad research; Admap, September.

Percy, Larry, Flemming Hansen and Rolf Randrup (2004) How to measure brand emotion; Admap, November 2004

Pham, M. T, Cohen, J.B., Pracejus, J.W. \& Hughes, G.D. (2001) Affect Monitoring and the Primacy of Feelings in Judgment, Journal of Consumer Research, 28, pp. 167-188, September.

Plassmann, Hilke, Peter Kenning, Michel Deppe, Harald Kugel, Wolfram Schwindt and Dieter Ahlert (2005) The Fire of Desire: Neural Correlates of Brand Choice; proceedings of EACR.

Plutchik, R. (1980) Emotion: A Psychoevolutionary Synthesis. New York: Harper \& Row.

Plutchik, R. \& Kellerman, H. (1974) Emotions Profile Index Manual, Western Psychological Services. Los Angeles.

Richins, M.L. (1997) Measuring Emotions in the Consumption Experience, Journal of Consumer Research, 24, Sep., pp. 127-142.

Shiv, B. \& Fedorikhin, A. (1999) Heart and Mind in Conflict: The Interplay of Affect and Cognition in Consumer Decision Making, Journal of Consumer Research, 26(3), Dec.

Wolak, Jennifer, MacKuen, Michael \& Keele, Luke (2003) How the Emotions of Public Policy Affect Citizen Engagement and Public Deliberation, Presentation at the annual meeting of the Midwest Political Science Association, Chicago, IL, April 3-6.

Zajonc, R.B. (1968) Attitudinal Effects of Mere Exposure, Journal of Personality and Social Psychology, 9(2), June

FLEMMING HANSEN, Econ.Dr., Professor; Department of Marketing, Center for Marketing Communication, Copenhagen Business School, Solbjerg Plads 3, C3, DK-2000 Frederiksberg, fh.marktg@cbs.dk

STEEN LUNDSTEEN, MSc., Research Assistant; Department of Marketing, Center for Marketing Communication, Copenhagen Business School, Solbjerg Plads 3, C3, DK-2000 Frederiksberg, sl.marktg@cbs.dk

SVERRE RIIS CHRISTENSEN, MSc., Associate Director; TNS-Gallup, Masnedøgade 22, DK-2100 København, sverre.riis.christensen@tns-gallup.dk 